\title{
Morality vs. Legality: European Responses to the Changing Norms Of Military Intervention
}

\author{
Aleksandra Krakiewicz
}

\section{Introduction}

The norms of armed intervention are undergoing significant change. According to the UN Charter, resort to force should only occur for the purpose of either self-defence or collective security authorised by the UN Security Council. More recently, however, new threats to security by global terrorist networks and non-state actors as well as calls for intervention in cases of human rights violations have challenged these exclusive criteria for legitimate use of force. The traditional principles of sovereignty and non-intervention ordering the international system are being redefined in a globalised world. In cases of humanitarian crisis, the emphasis is now shifting away from the right of intervention towards the responsibility of states to protect vulnerable populations at risk from civil wars, insurgencies, state repression and state collapse. In other words, where governments are unwilling or unable to protect their citizens from avoidable catastrophe, the international community of states is now believed to have a responsibility to act. The notion of 'humanitarian intervention' and the 'responsibility to protect', endorsed in the 2005 World Summit Outcome document, will require significant readjustments of the rules of military engagement.

The challenge to the existing normative framework regarding the use of force is further complicated by the fact that the United States is now the world's pre-eminent military power. Its hegemonic position in the post-Cold War world order is raising new questions about the balance of power in the international system. The current Bush administration, moreover, is setting controversial paradigms as far as the extension of the notion of self-defence, preemptive action and the legitimacy of unilateralism are concerned. The debate which preceded the attack on Iraq in March 2003 addressed this whole range of issues related to the legality of intervention. The Bush administration put forward several different lines of argument to justify a possible strike against Iraq. From summer 2002 onwards, members of the administration variously suggested that military action was necessary and justified because of the urgent need for an end to the repression of the Iraqi people, for regime change, and for pre-emptive action against an imminent threat. They also spoke of Iraq as the 'next phase' of the war on terrorism. Finally, they stressed the importance of securing the implementation of Security Council resolutions on Iraq, particularly those relating to biological, chemical and nuclear disarmament. When the US finally took military action against Iraq in March, the government relied on one main legal rationale: Iraq's failure to implement certain UN Security Council resolutions, and the coalition's continuing authority to use force based on such resolutions (Roberts 2003: 39).

In view of these controversial developments an essential question is: what type of responses have been given by the United States' principal allies, the Europeans? Since the end of the Cold War order, Europeans have been facing the question of how they want to engage with 
the rest of the world, how they define their relationship with the United States and when they are prepared to resort to military force.

It has often been suggested that international law and multilateralism are the constitutive principles Europeans could always be sure to agree on (Risse 2003). In reality, the case is not quite so simple. What constitutes an imminent threat? When is pre-emptive action justified? How can multilateralism be made effective? Does effective multilateralism include the threat of unilateralist action? Reference to a general belief in the importance of international law and the desirability of multilateral action does not actually get us very far in understanding European responses to these pressing questions. In this context, it is often overlooked that the European perception of international justice and multilateralism is not uniform, but that there are instead many differing forms and rationales behind the more general approval of it. The Iraq crisis provides a compelling illustration of these different perceptions.

How did individual European governments relate to the discussion about the legitimacy of the attack against Iraq? This article argues that diverging European positions on the Iraq intervention reflect distinct approaches to the international normative framework regulating the use of force. It identifies two types of positions - legal and moral. Evidence for the validity of this distinction is provided by an examination of the foreign policy lines adopted by Germany, Poland and the United Kingdom. The fact that these three countries provided very different justifications for supporting or opposing the US-led war on Iraq presents us with a complex puzzle. Considering the vital role Germany, Poland and the United Kingdom can be expected to play for the future of European unity; there is a pressing need to explain the reasoning underlying their divergent positions on Iraq. These divergences, it is concluded, will continue to pose problems for forging a concerted European policy on the use of armed force in international affairs.

\section{Conceptualising contending approaches to the legitimate use of force}

In the context of the Iraq war, the European debate about the legitimate use of force was characterised by two distinct approaches - the one legal and the other moral. The former concentrates on the legality of the use of force on the basis of the UN Charter while the latter is focused on the legitimacy of the use of force in defence of human rights against dictatorships. Analyses of European positions on the war often seem to conflate these two approaches.

The first of these approaches essentially focuses on the rules governing the international system and relations between states; the second, conversely, concerns the moral duty of democracies and relations between states and societies. As Nicole Gnesotto puts it:

The legalistic rhetoric about the use of force leads to greater importance being given to the stability of the international system compared with the democratisation of societies, and order as opposed to liberty, even if that means ignoring tyrants in the name of international law. [.]The argument of ethics has the opposite defect of attaching greater importance to liberty at the expense of stability in the world, even though it may mean upsetting regional balances and in particular destroying, in the name of democracy, the legal foundations of a system that is essential to the very actions of democracies. (Gnesotto 2003: 31-32).

Thus while the legal approach is more concerned with the rules and procedures of the international community in order to maintain peaceful relations among states, the moral stance stresses the protection of liberal values, human rights and democracy. The latter may thus be prepared to extend the goals of legitimate use of force beyond the conventional notion of self-defence to include humanitarian intervention or regime change. The two approaches also propose different strategies for reforming the existing legal framework of armed intervention. While both may agree that the existing international rules are somewhat flawed, the 'moral' side will choose a proactive approach and act on what it considers to be 'right'. Legalists will insist on waiting until formal reform of the law has occurred and only then act according to those principles. In this sense, the moral approach prioritises substance 
whereas the legal approach puts greater emphasis on procedure. In other words, both approaches share a general willingness to abide by the law, yet where current legal provisions are deemed insufficient to meet contemporary challenges, representatives of the moral view are ready to act on purely moral grounds.

Therefore, it is important to note that the labels are by no means supposed to imply that the moral view is not concerned with international law and, vice versa, that the legal argument is deprived of ethical foundations. Similarly, the term 'moral' in this context does not imply any kind of value judgement. This stance is not regarded as more just or normatively desirable than the legal approach. The labels are intended to refer to an emphasis made by their adherents; they suggest a particular line of reasoning underlying government decisions. This article posits that the distinction between legal and moral interpretations of the legitimate use of force captures the essence of the divergent arguments put forward by European states with regard to the rightfulness of military intervention in Iraq. In order to illustrate the relevance of this distinction, it examines four central issues in the debate about the legality of the intervention, specifically WMD, human rights, UN Resolutions, and multilateralism. The article shows how the way in which foreign policy elites in each of the three countries under investigation weighed these factors against each other indicates whether priority is given to a legal or a moral interpretation of international norms with regard to military interventions.

\section{The United Kingdom}

Since the coming to power of the Labour government in 1997, there has been a shift in the content and conduct of British foreign policy. British policy, Foreign Secretary Robin Cook announced in May 1997, was to be guided by the goals of security for all nations, universal moral values, the promotion of democracy and human rights. In short, British foreign policy was to assume an 'ethical dimension' (Wickham-Jones 2000: 4). The two central ethical commitments of the new foreign policy line were, firstly, that Britain must play an active part in the international community by complying with its rules and co-operating with its institutions; and secondly, that Britain should use its influence to protect and strengthen liberal and social democratic values such as human rights, democracy, poverty reduction and good governance (Wheeler and Dunne 2004: 6-7). That these twin foundations may occasionally conflict was soon to become apparent.

Under the New Labour government, British troops have been deployed to Kosovo in 1999, Sierra Leone in 2000, Afghanistan in 2001 and Iraq in 2003. Moral and humanitarian concerns have been brought forward by the government in each of these cases. With regard to the war in Kosovo, Prime Minister Blair declared that it was a 'just war, based not on territorial ambitions but on values' (Wickham-Jones 2000: 16). Yet, how does Blair's definition of what constitutes a 'just war' relate to the existing international normative framework of military intervention? In a critical speech in Chicago in April 1999, Blair put forward the case for suspending the traditional non-intervention norm in grave cases such as genocide. Crucially, Blair also spelled out five criteria which could justify the decision for armed intervention. He said that Britain must be sure of its case, exhaust all diplomatic possibilities, be confident that military force will be successful, commit to long-term post bellum reconstruction and its own interests must be at stake (Blair 1999). As Wheeler and Dunne rightly point out, the glaring omission from this list is the issue of right authority and UN mandate (Wheeler and Dunne 2004: 21). The crucial question of legitimate authority was to come back on Blair. The British reasoning about going to war with Iraq reflected the aforementioned dilemma between adhering to international rules and defending liberal, humanitarian values.

Weapons of mass destruction played a central role in the British justification for war against Iraq. The government engaged in a huge effort to demonstrate to the public that there was sufficient evidence for the existence of those weapons in Iraq and, in an unprecedented move, even published, on 24 September 2002, a security dossier based on the findings of the British Joint Intelligence Committee which presented the available intelligence material regarding Iraq's chemical and biological weapons programme. In February, a second dossier, which came to be known as the 'dodgy Dossier', was released. It was suggested that Saddam 
Hussein possessed weapons that could be deployed and reach Britain within forty-five minutes. The implications of this claim were important as they portrayed Iraq as an 'imminent threat' to British security and could thus provide the crucial justification for military action. References to the threat posed by WMD were also extensively made in parliamentary debates, where it was stressed that disarmament was the central goal of the campaign (Blair 2002; Blair 2003; HM Government 2003). However, there was considerable doubt regarding the truthfulness of the allegations.

It is crucial, then, that the argument about WMD was bolstered by severe human rights concerns. In view of a number of possible threats from WMD worldwide, the government had to explain why it was Saddam Hussein who had been singled out. The Prime Minister thus frequently stressed the atrocities and human rights violations committed under Saddam's rule, whether against Kurds, Shia Muslims, Kuwaitis or political opponents (Blair 2002).

Humanitarian intervention poses some difficult challenges to the existing provisions of the UN Charter that are based on the norm of non-intervention in recognition of state sovereignty. As Charles Grant rightly argues:

[...] both Bush and Blair [...] have challenged the Westphalian principle that sovereign states should be immune from outside interference - though from different perspectives. Blair's doctrine of humanitarian intervention is about intervening to prevent abuse of human rights. The Bush doctrine, of pre-emptive war and regime change, is a response to the threat of terrorism and rogue states. (Grant 2003).

It is because of this emphasis on human rights that some commentators have been inclined to conclude that 'where Tony Blair is unusual is the extent to which his policy seems motivated by a sense of moral indignation at human suffering and injustice, and his willingness to take military, and by implication domestic, political risk' (Mangold 2001: 25). The centrality of human rights for New Labour's foreign policy, as already spelled out in Robin Cook's 1997 landmark speech (Cook, quoted in: Wheeler and Dunne 2004: 12-13), continues to provide a crucial source of justification for the use of force in British foreign policy.

The question of just cause for military intervention aside, the question of legal authority is another key tenet in the debate about legitimate use of force. The British government made a considerable effort to secure UN authorisation for a strike against Iraq. Following a meeting between Blair and Bush at Camp David on 7 September 2003, Britain co-operated closely with the Bush administration in order to elaborate a compromise for passing a fresh UN resolution on Iraq. From the British perspective, the aim of the resolution was to tie the US into a multilateral framework while at the same time upholding the US position on the need to set a deadline for Saddam Hussein to disarm. The US-UK proposal was presented to the Security Council and after some modifications regarding the resort to war (the text contains no automatic resort to war but on the other hand there is no explicit requirement to pass a second resolution before military action either), a compromise was reached and Resolution 1441 passed unanimously by the Security Council on 8 November 2002.

With the weapons inspectors not finding any evidence of WMD in Iraq but at the same time Saddam Hussein not co-operating satisfactorily with them, the pressure to prolong inspections or authorise a military strike mounted from early January 2003 onwards. The UK argued strongly in favour of a second resolution authorising the use of force, while France, Germany and Russia remained opposed. The Americans pushed for action so that by midMarch it became clear that a second resolution was unlikely to be passed. Under these circumstances, the British government had to decide whether to stand by the United States and potentially initiate military action without a fresh UN mandate. In the absence of a second resolution, the Prime Minister remained firm in his support for the Bush administration. On 17 March, Bush, Blair and the Spanish Prime Minister Aznar issued a 24hour ultimatum for Saddam to fully comply with UN requirements. On 20 March 2003, British forces joined the US in their attack against Iraq. 
It is important to note, however, that the UK government insisted that it had attempted to secure a second resolution not in order to obtain legal authority for military action. The government's view regarding a second resolution was that 'politically, it is a better way of binding in the international community' (HC Foreign Affairs Committee 2003) Formal legal authority had, according to the Government's interpretation, already been secured through previous Security Council Resolutions since the 1991 Gulf War. More specifically, the British government decided to follow the opinion of the Attorney General, who put forward the argument that past Security Council Resolutions provided a continuing, or revived, authority to use force, even more than a decade later and under different circumstances. ${ }^{1}$ Adam Roberts has termed this the concept of 'continuing authority'. Following Iraq's invasion of Kuwait, Resolution 678 (29 November 1990) authorised UN member states to use force not just to expel Iraqi forces from Kuwait, but also 'to secure international peace and security in the area'. Resolution 687 ( 3 April 1991) set out the terms of the ceasefire and imposed obligations on Iraq to destroy its weapons of mass destruction programmes. Subsequently, numerous Security Council resolutions found Iraq in breach of the ceasefire commitments. It was, therefore, argued by the British government that the legality of action against Iraq did not result from Resolution 1441 in isolation but from Iraq's repeated violation of various UN resolutions and the continuing authority of the international community to take action contained in those resolutions.

However, as Roberts points out, the concept of 'continuing authority' remains contested. He argues that 'the greatest difficulty with 'continuing authority' in the light of events in Iraq in 2003 concerns not so much the proposition itself which is fundamentally strong, but its particular invocation in the crisis'.2 Numerous members of the international community, including members of the UN Security Council, explicitly rejected the notion as a justification for intervention in Iraq. In addition to a degree of legal uncertainty there was thus substantial political contestation undermining the multilateral framework for dealing with the threat.

The fact that the United Kingdom decided to participate in the US-led strike against Iraq without clear authorisation from the Security Council has prompted some observers to question the British commitment to international legal requirements and the credibility of New Labour's 'ethical' foreign policy. The evidence here suggests that there is no doubt the British government would have preferred to act with a clear mandate from the Security Council and it did seek to find a legal justification for the intervention. In that sense, there is still a general commitment to the UN, its legal framework and multilateralism. The problem was that several other members of the Security Council did not share the British interpretation of the legal foundations for war. Thus, where the UK stands out is in its preparedness to opt for unilateral action where a Security Council consensus could not be achieved. Tony Blair eventually concluded that the greater danger to the UN is inaction: that to pass Resolution 1441 and then refuse to enforce it would do the most deadly damage to the UN's future strength, confirming it as an instrument of diplomacy but not of action, forcing nations down the very unilateralist path we wish to avoid. (Blair 2003).

This aspect relates to essential current questions in the debate about maintaining credibility and effectiveness in international co-operation and inside the UN in particular. When, if ever, is one willing to back multilateralism by the threat or even actual use of unilateral action? It seems that the answer given by the Blair government is that if multilateral agreement fails, resort to unilateralism and flexible 'coalitions of the willing' cannot be ruled out. It is plain that the British government prefers action through multilateral organisations, in particular the United Nations and is concerned about the possible weakening of this organisation as a result of the Iraq crisis. However, Blair has also made clear that, where effectiveness and credibility are at stake, unilateral engagement cannot be excluded as an option. The coalition with the United States was thus viewed as legitimate to commence military action against the regime of Saddam Hussein.

The British position therefore fulfils the criteria of the moral approach to international norms. It represents a complex view, trying to find a balance between prevailing norms and multilateral institutions on the one hand, and an effective response to new security threats and human rights violations on the other. Crucially however, where the two are in conflict, as 
in the Iraq context, the UK government gives priority to moral considerations over legal arguments.

\section{Poland}

In 1999, in a parliamentary debate about the NATO intervention in Kosovo, Foreign Minister Geremek summarised his government's position as follows:

The ideal case is to have a Security Council mandate for such missions. At the same time, however [...] given the entire veto technology in the Security Council, one must not make NATO's moves contingent on the votes of either Russia or China, or both. NATO's missions going beyond Article 5 in emergencies may be pursued by NATO when they are consistent with the principles of the United Nations Charter and are in the service of the values enshrined therein' (Geremek 1999).

Reflecting this view, Polish political elites concurred that although the situation was not ideal, where human rights were at stake, their defence should take precedence over the sovereignty of a state (Oscia 2003: 30-31). During the debate over the legality of the Kosovo war, Poland had therefore let itself be known as an ally for whom the lack of a solid legal basis was no obstacle to allied operations. Was there a similar attitude to the Iraq intervention, and if so, on what other grounds did Poland seek to legitimise the war?

One striking feature in the Polish debate has been the readiness with which Saddam's possession of WMD was assumed. The Polish government argued 'that the threat posed by weapons of mass destruction in the hands of the Iraqi dictator, especially in the context of international terrorism, fully justifies military action, which aims at preventing the potential use of those weapons' (Government declaration 2003). Moreover, the Foreign Minister suggested that one should actually not ask what evidence there was for Iraq's WMD. Instead, he said, the burden of proof was on Iraq to show that it had destroyed its weapons (Cimoszewicz 2003b). In view of the controversy about what constituted sufficient evidence of Saddam's WMD, and who had the authority to decide what evidence was deemed sufficient, Warsaw's position shows little consideration for contentious legal matters. It is also somewhat different from the British case, where the government went to great lengths to prove to the public, Parliament and its own party that Iraq's WMD did indeed pose a threat to international security.

A second factor with great impact on the Polish debate in the lead-up to the invasion was the concern for human rights. The argument was made that Saddam Hussein had to be prevented from further human rights violations and atrocities against his own population. Liberating the Iraqi people and giving them the chance for democratic nation-building were set out as important objectives of the intervention. A factor that strongly influenced the Polish debate in this context was the analogies drawn with Poland's own history. The first analogy regarded the appeasement strategy of Western powers vis-à-vis the Third Reich. It was in this vein that Adam Rotfeld compared the Europe-wide peace demonstrations of 15 February to the enthusiastic reception of Arthur Neville Chamberlain on his return from Munich in 1938, where he had agreed to grant the Sudetenland to Nazi Germany. Rotfeld commented that 'Chamberlain thought he had secured peace for all times, [and a few months later] Hitler's Germany occupied Czechoslovakia and a year later attacked Poland' (Rotfeld 2003). It was argued, therefore, that Poland and the international community could not stand by to watch Saddam Hussein continue with his despotic rule.

The second analogy concerned the Polish communist past and its struggle for liberation from Soviet domination. Several commentators agree that it was due to Poland's past as a communist state that the country felt it had a special responsibility to support the spread of democracy to other parts of the world (Rotfeld 2003; Oscia 2004). The arguments put forward by policy-makers did, in fact, reflect Warsaw's broader commitment to proactive engagement aimed at promoting Western values of freedom and democracy worldwide. Similarly, the Polish vision for the role of NATO marks Poland out as a staunch supporter of a redefined 
NATO mission to act as a guardian of freedom, democracy and human rights (Cimoszewicz 2002b). This sense of a moral duty to act was used by Polish elites as a central source of justification for the invasion. Yet, beyond historical and moral arguments, what legal basis was regarded as legitimating the attack?

In an official statement the Polish foreign ministry argued that Resolution 687 did not annul the authority to use force that derived from Resolution 678. Rather, it set out the conditions for Iraqi disarmament and a mechanism for monitoring progress made in this respect. A whole array of Security Council resolutions found Iraq in breach of the outlined provisions. Resolution 1441 was then the 'last chance' for Iraq to fully comply with UN demands. The warning that Iraq had to expect 'serious consequences' in case of continued defiance was interpreted to include the use of force. Therefore, although reference is made to the continued authority of previous Resolutions, it seems that Polish authorities considered Resolution 1441 in itself as a sufficient justification for the attack. In view of the international controversy surrounding the interpretation of Resolution 1441, and some parties explicitly rejecting the notion that the use of force was implicit in the wording of Resolution 1441, Polish reliance on this particular provision is somewhat problematic. It would be hard to sustain the claim that Warsaw's line of reasoning provided solid legal grounds for the intervention.

The attitude Polish elites displayed towards securing a UN mandate for the war in Iraq conforms to Warsaw's more general approach to international norms. Poland would like to see significant reforms of the UN Charter if the latter is to remain the principle basis of international law. The call for a re-consideration of prevailing norms governing military interventions derives from a perception of a changed nature of the international system. In the context of the intervention in Iraq, the Polish government declared it was aware of the contending opinions on the legal basis for military action. It concluded that the differences resulted from an international situation that had no precedent and posed a threat to international peace and security that was of a qualitatively different character than in the past (Polish Government 2003). Reflecting this attitude, President Kwasniewski suggested that 'today's reality prescribes the adoption of a new legal act that would live up to current challenges and lay out a political philosophy for today and the future' (Kwasniewski 2003).

In line with this position, Foreign Minister, Cimoszewicz, presented a proposal for political reform of the UN system to the General Assembly in September 2002 aimed at adjusting the UN to the new requirements of the 21 st century (Cimoszewicz 2002a; Cimoszewicz 2003a; Rotfeld 2002). The essence of the proposal is to keep the UN Charter as a foundation text and supplement it with a new political document that could address current challenges to international peace and security. The new provisions would involve making the UN machinery more efficient, establishing a system of cooperation with regional organisations and strengthening ties with non-state international actors. The need to reform the principles underlying UN actions is also mentioned. With regard to the prevailing non-intervention norm, the proposals are in line with similar statements made by the Foreign Minister and the President. President Kwasniewski has argued, for example, that the principle of state sovereignty cannot be used as a 'shield against international law. [...] The international community must have the possibility to intervene. Those who break the law cannot go unpunished' (Kwasniewski 2003). On the one hand, this can be viewed as a strong call to abide by and enforce international law. On the other hand, Kawsniewski's statement poses a substantial challenge to the notion of sovereignty, the basic ordering principle of the international system, and its function as the foundation of the non-intervention norm. It is thus clear that, in line with the defining criteria of the moral approach to international norms, the maintenance of stability in international order is not given priority over other considerations, such as the liberation of repressed peoples. In this sense, recent policy developments in Poland seem to indicate an affinity in outlook between Washington and Warsaw on vital security policy principles. The two defining tenets of Polish strategic culture, which coincide with current American security thinking, are, firstly, a disposition to favour proactive engagement and secondly, a desire to revise existing international norms in the light of recent challenges to international security. This attitude could already be observed during the 1999 Kosovo war. Unlike Germany or France, Poland did not see a serious debate 
about the legality of NATO action without a UN mandate. It was assumed that although it would be better to act with a UN mandate, international law was less important than preventing the spread of instability in the Balkans (Zaborowski 2003: 6). In the case of Iraq, Polish elite support for Washington's policy remained strong throughout the conflict and no demands were made for an explicit authorisation of the use of force by the Security Council. Maintaining the partnership with America was given priority over working towards a broader international consensus. Thus, when deemed necessary, Warsaw is not reluctant to take unilateral action.

On the whole, the evidence presented here suggests that Warsaw's approach to international norms falls into the category described as 'moral' due to the willingness to revise the existing legal framework through proactive engagement in conflict resolution. In this sense, there are some important parallels with the British line of argument discussed above. Yet, questions regarding the legitimacy of war were much less disputed among the Polish political elite, particularly with respect to the evidence for Iraq's WMD programme. Thus although both Poland and the United Kingdom fall into the 'moral' category, Poland's strong willingness to rely on purely moral arguments places it somewhat closer to the current US line of reasoning.

\section{Germany}

Over the last fifteen years, Germany has undergone significant changes in its attitudes towards military force. From a policy of complete abstention from military deployments in any of NATO's so-called 'out-of-area missions', Berlin had moved to participation in a range of operations in the Balkans, East Timor and Afghanistan. This development is remarkable, considering the previous cross-party consensus until 1990 that the constitution did not allow for a deployment of German forces beyond NATO territory and for any purposes other than the defence of the Federal Republic. It was during the 1990 Gulf War that this domestic consensus began to crumble and, crucially, that Germany's allies started voicing expectations of a German engagement that went beyond financial and logistic support. The domestic controversy on the issue was settled by a ruling of the German Constitutional Court on 12 June 1994, which declared Bundeswehr operations within a 'system of collective security' compatible with the Basic Law under Art. 24 (2). The ruling paved the ground for military action to become a legitimate tool in German foreign policy (Bos 2003: 218-219). It is important to stress that under the red-green government, the interpretation of Germany's special moral obligations in this respect has significantly evolved. The traditional argument that German history imposed a logic of restraint was reversed to suggest that Germany had a special duty to participate, also militarily, in international conflict resolution. Hence the fundamental question to be addressed in this context is what limits and possibilities there are for Germany's willingness to use military force.

There is indeed a significant number of authors who argue that Berlin's Iraq policy was determined by ideational factors and Germany's persisting 'culture of restraint' concerning the resort to military force (Dalgaard-Nielsen 2003; Larres 2003; Müller 2003). According to this view, unless most Western democracies are on board, and unless a military intervention serves a convincing humanitarian purpose, Germans will be reluctant to line up. Schröder's opposition to another Gulf war may have been politically opportunistic, but it also reflected the particular nature of Germany's strategic culture (Dalgaard-Nielsen 2003: 110). So does the German government's attitude reveal a fundamentally different approach to international norms that can serve to explain the German opposition to war in Iraq?

First, it is important to note that the German government questioned the WMD argument as a valid justification for war against Iraq using several different lines of argument. Foreign Minister Fischer cast doubt whether WMD were really the underlying motive for Washington's Iraq policy. In a speech to Parliament on 15 November, he suggested that if an actual threat assessment regarding WMD were carried out, it would certainly not lead to the conclusion that Iraq should currently be the central focus of concern (Fischer 2002b). Chancellor Schröder made similar remarks and insisted that in the absence of clear intelligence 
information on Iraq's weapons arsenal, UN inspections should continue (Schröder 2002; Schröder 2003a).

Furthermore, the German government ruled out the possibility of the issue of WMD becoming entangled with the global fight on terrorism. Fischer frequently referred to this problem as one of getting the priorities right. For him, the first priority should be the fight against international terrorism and the second should be the resolution of regional conflicts (Fischer 2002b). As Harnisch writes, in Germany a consensus emerged that pre-emptive military action against terrorists with a UN mandate was acceptable, but this consensus did not include pre-emptive military action against (potential) weapons of mass destruction in member states of the 'axis of evil'. Thus, the Schröder government opposed a 'silent extension' of the mission spectrum with respect to the proliferation of weapons of mass destruction, in particular in Iraq (Harnisch 2004: 10).

Human rights violations by the regime of Saddam Hussein were, of course, acknowledged and condemned by German authorities. Saddam's rule was referred to as 'a brutal tyranny', 'a terrible regime for the Iraqi people' and a threat to the entire region. It was noted that Iraq had attacked neighbouring Iran and Kuwait, fired missiles against Israel and used chemical gas against its own Kurdish population (Fischer 2002a). However, in the absence of clear legal provisions under the existing UN framework, there was no argument made that the violation of human rights by Saddam could justify a military attack. Instead, Foreign Minister Fischer stressed the German commitment to established criteria of the just war framework, namely last resort, proportionality, compelling evidence of an imminent threat and right authority. Moreover, he expressed considerable concern about the destabilising effects an intervention could have on the entire region. In this context, he pointed out the large post-bellum responsibility the coalition would have to assume to reconstruct and stabilise the country and region.

During negotiations over Resolution 1441, Fischer stressed that the text should not contain any automatism that would justify immediate military action in the case of Iraqi noncompliance and that Germany would instead advocate a two-resolution approach. Moreover, the importance of multilateralism and international co-operation was stressed as a matter of general principle but also as a crucial achievement in the global fight against terrorism which should not be jeopardised by imprudent unilateralist action. The federal Government's position was that the attacks of $9 / 11$ had created new 'opportunities to further the development of multilateralism, to stimulate a more intensive dialogue of civilisations and to create a platform from which to strike at the roots of terrorism' (Federal Foreign Office 2002).

However, the strong statement by the German government was that in the particular case of Iraq, Germany would not participate in military action even with a UN mandate. This declaration had been made by Chancellor Schröder during his election campaign and was restated by Foreign Minister Fischer on 27 September 2002 (Harnisch 2004: 12). Can their position be explained in the context of Germany's continued reluctance to use military force? The Chancellor was certainly concerned not to let war become just another 'normal' means of politics and reiterated that resort to military force, no matter by whom, had to rest on certain principles and possibilities enshrined in the UN Charter (Schröder 2003b). It also seems plausible to suggest, however, that the categorical rejection of the use of force in the Iraq case was a result of the German 'culture of reticence' coinciding with a new German assertiveness in foreign policy, and vis-à-vis the US in particular. Moreover, there was considerable domestic pressure on the Government not to upset public opinion in the lead up to elections and preserve the unity of the red-green coalition, which had already been considerably strained by the Kosovo and Afghanistan interventions.

The German red-green government has been an active supporter of UN reform, including most notably important proposals for restructuring the Security Council as well as enhancing the cooperation with non-government organisations and improving the protection of economic and social human rights. ${ }^{3}$ However, with regard to the legitimate use of force, the German government represents an attitude towards international norms that differs markedly from the Polish and British approach in the sense that it adopts a stricter interpretation of the 
existing legal framework. There is great reluctance to extend the mission of UN action to allow more readily for military intervention for goals such as regime change, democratisation or the fight against weapons of mass destruction. Instead, strong emphasis is placed on maintaining order and stability in the international system, for which observance of the existing rules of the United Nations was deemed essential. Germany thus conforms to the model of a legal approach to international norms.

\section{Conclusion}

The reform process of the United Nations is at a crucial stage and key aspects of the existing framework for the legitimate use of force are currently being re-defined. With the Bush administration proposing a number of new concepts and paradigms, such as the extension of the notion of self-defence and pre-emptive action, it is important for Europeans to participate in and shape the current reform debate. The above discussion of intra-European disagreements over the rightfulness of the military campaign in Iraq, however, has identified several important differences among European governments pertinent to some of the most topical problems in the reform of the international norms of military intervention. Germany continues to adhere to a markedly more legal approach, whereas the United Kingdom and Poland take a more moral approach in the sense that they are willing to act on ethical principle in the absence of revised legal provisions to respond to the new challenges to global security. Beyond their general support for the United Nations and international law, European governments thus seem to be giving rather different responses to some of the important challenges posed by the new international security situation and US proposals on this matter. The question remains: how significant are these differences for the prospect of future European unity?

It is important to note that the European debate about rightful intervention is characterised by arguments about the 'when' rather than the 'if'. Among European governments, we do not find the traditional non-interventionist positions of either pacifism, which rules out intervention altogether, or realism, which rules out intervention for humanitarian or other reasons beyond narrowly defined security interests. There is, therefore, some fundamental underlying agreement on the need to intervene in the name of human rights and democracy and as a result of a new, broader understanding of security. A European consensus on the necessary conditions for such interventions has, however, evidently not been reached.

It is clear that the Iraq crisis did not mark the end of CFSP or ESDP. On the contrary, several aspects of ESDP have been strengthened and common missions such as EUPM in Bosnia, Operation Concordia and Operation Artemis have been launched during and shortly after the Iraq crisis. In this sense, the Iraq crisis may even be said to have had a 'cathartic' effect on common European defence (Menon 2004).

However, with regard to the specific question of the rightful use of military force, no such progress could be seen. After the Iraq crisis had revealed discrepancies in European positions on this matter, it was widely regarded as an important step forward that the EU presented, in December 2003, its first common Security Strategy. The European Security Strategy concludes that 'we need to develop a strategic culture that fosters early, rapid, and when necessary, robust intervention' (European Security Strategy 2003: 11). It therefore recognises, for the first time in the history of CFSP/ESDP, that the use of force may be required. What is missing from that document, however, is a discussion of when robust military intervention would be deemed necessary and legitimate. In the light of the findings of this article, this glaring omission may not be surprising; but it is, nonetheless, highly problematic because it illustrates the continuing inability on the part of European governments to agree on a common response to the changing norms of military intervention. The disagreements on this issue can be expected to cause considerable difficulty in forging a Europe-wide consensus with regard to the use of force in EU foreign policy.

This article was originally presented as a paper at the European Foreign Policy Conference, London School of Economics, July 2005. 


\section{Notes}

1 It should be noted that there is now considerable controversy regarding the political pressure Lord Goldsmith was put under to make the legal case for invading Iraq. There are allegations that he changed his original position to support the government's cause and that this deliberately coincided with the crucial Commons vote on the invasion. If these allegations were to be confirmed in the future, this would support the present argument that legal considerations were less important for British decision-makers than their moral arguments. See for example: The Independent, 25 March 2005.

${ }^{2}$ In particular, even if the US and its allies have continuing authority to use force, it remains a question whether that entitled them to launch a full-scale attack to achieve regime change. In addition the notion of 'continuing authority' is undermined by the unclear evidence that Iraq still possessed WMD. There was scope for disagreement as to whether the UN verification system, operating under Resolution 1441, should have been set aside in favour of armed force when the inspectors were able to visit sites throughout Iraq and the disarmament process had produced at least some results. Adam Roberts, cited in .Foreign Policy Aspects of the War on Terrorism., HC 405.

${ }^{3}$ Reform of the Security Council has become the focus of German reform proposals. Other important initiatives have included the 'Global Partnership' resolution, support for the GlobalContact-Initiative and a range of other resolutions on co-operation with the private economy and NGOs. See Christian Hacke, Die Außenpolitik der Bundesrepublik Deutschland. Von Konrad Adenauer bis Gerhard Schröder, Frankfurt a. M.: Ullstein, 2003, esp. p. 483-500 and Manfred Knapp, .Die Rolle Deutschlands in den Vereinten Nationen., Aus Politik und Zeitgeschichte, B27-28/2002.

\section{References}

Blair, Tony (1999). 'The Doctrine of the International Community', Economic Club of Chicago, 22 April 1999, available at: http://number-10.gov.uk/output/Page1297.asp.

Blair, Tony (2002). Prime Minister's Iraq Statement to Parliament, 24 September 2002, available at: http://number-10.gov.uk/output/Page1727.asp.

Blair, Tony (2003). Prime Minister's statement opening the Iraq debate, 18 March 2003, available at: http://number-10.gov.uk/output/Page3109.asp.

Bos, Ellen (2003). 'Deutsche Außenpolitik nach dem 11. September 2001: Von der "uneingeschränkten Solidarität" zum "deutschen Weg"', in Ellen Bos and Antje Helmerich (ed.), Neue Bedrohung Terrorismus. Der 11. September 2001 und die Folgen. Münster: LIT.

Cimoszewicz, Wlodzimerz (2002a). Statement at the 57th Session of the General Assembly of the United Nations, 15 September 2002, available at:

http://www.msz.gov.pl/start.php?page=1310900001.

Cimoszewicz, Wlodzimierz (2002b). 'The Polish view on the role of NATO', 30 October 2002, available at: http://www.polishembassy.ca/files/polish\%20view\%20\%20nato.pdf.

Cimoszeicz, Wlodzimierz (2003a). 'Polish foreign policy in the year 2003', Speech by the Foreign Minister in the Sejm, 22 January 2003, available at:

http://www.msz.gov.pl/start.php?page=1020103031.

Cimoszewicz, Wlodzimierz (2003b). Sejm debate on Polish military participation in Iraq, 26 March 2003, available at: $\quad$ http://www.msz.gov.pl/start.php?page=1350302110.

European Security Strategy (2003). 'A Secure Europe in a Better World', Brussels, 12 December 2003, available at: http://ue.eu.int/uedocs/cmsUpload/78367.pdf.

Dalgaard-Nielsen, Anja (2003). 'Gulf War: The German Resistance', Survival, 45 (1): pp. $24-34$. 
Federal Foreign Office (2002). 'Sixth Report of the Government of the Federal Republic of Germany on its Human Rights Policy in the Context of Foreign Relations', Berlin, June 2002, available at:

https://www.auswaertiges-

amt.de/www/de/infoservice/download/pdf/publikationen/mrb6 en.pdf.

Fischer, Josef (2002a). 'Für ein System globaler kooperativer Sicherheit'. Speech at the 57th General Assembly of the United Nations in New York, 14 September 2002, printed in Stichworte zur Sicherheitspolitik, No, 9, September 2002, Presse- und Informationsamt der Bundesregierung, Berlin

(available electronically at: http://www.bundesregierung.de).

Fischer, Josef (2002b). Speech to the German Bundestag, 15 November 2002, printed in Stichworte zur Sicherheitspolitik, No. 11, November 2002, Presse- und Informationsamt der Bundesregierung, Berlin.

Geremek, Bronsilaw (1999). Sejm debate on the directions of Polish foreign policy, 8 April 1999, available at: http://www.zbiordokumentow.pl/1999/1-2/20.html.

Gnesotto, Nicole (2003). 'EU, US: visions of the world, visions of the other', in Gustav Lindstrom (ed.), Shift or rift: Assessing US-EU relations after Iraq. Paris: EU Institute for Security Studies.

Grant, Charles (2003). 'Blair.s five wars', Prospect magazine, (October edition).

Hacke, Christian (2003). Die Außenpolitik der Bundesrepublik Deutschland. Von Konrad Adenauer bis Gerhard Schröder. Frankfurt a. M.: Ullstein.

Harnisch, Sebastian (2004). 'German Non-Proliferation Policy and the Iraq Conflict', German Politics, 13 (1), pp. 1-34.

Her Majesty.s Government (2003). 'Iraq: Military Campaign Objectives', 20 March 2003, available at: http://number-10.gov.uk/output/Page3318.asp.

House of Commons Foreign Affairs Committee (2003). 'Foreign Policy Aspects of the War on Terrorism', 10th Report of Session 2002-2003, HC 405, available at:

http://www.publications.parliament.uk/pa/cm200203/cmselect/cmfaff/405/405.pdf.

Knapp, Manfred (2002). 'Die Rolle Deutschlands in den Vereinten Nationen', Aus Politik und Zeitgeschichte, B27-28/2002.

Kwasniewski, Aleksander (2003). Speech on transatlantic security, National Defence University, USA, 13 January 2003, available at:

http://www.prezydent.pl/x.node?id=1011848\&eventID=501062.

Larres, Klaus (2003). 'Mutual Incomprehension: US-German value gaps beyond Iraq', Washington Quarterly, 26 (2), pp. 23-42.

Mangold, Peter (2001). Success and failure in British foreign policy: evaluating the record. Basingstoke: Palgrave.

Menon, Anand (2004). 'From Crisis to Catharsis: ESDP After Iraq', International Affairs, 80 (4), pp. 631-648.

Müller, Harald (2003). 'German National Identity and WMD Proliferation', The Nonproliferation Review, pp. 1-20.

Osica, Olaf (2004) 'Irak - poczatek nowej epoki w polityce zagranicznej III RP?', Raporty i Analizy, Centrum Stosunkow Miedzynarodowych, 4/2004. 
Oscia, Olaf (2003). 'In Search of a New Role: Poland in Euro-Atlantic Relations', in Martin Zaborowski and David Dunn (eds), Poland: A New Power in Transatlantic Security. London: Frank Cass.

Polish Government declaration (2003). 'The legal bases justifying military action against Iraq', 20 March 2003, available at http://www.msz.gov.pl/start.php?page=1350302130.

Risse, Thomas (2003). 'Die neue Weltordnung: US-amerikanische Hypermacht . europäische Ohnmacht?', Welt Trends No. 39, Summer 2003.

Roberts, Adam (2004). 'Law and Use of Force After Iraq', Survival, 45 (21), pp. 31-56.

Rotfeld, Adam (2002). 'Strength in Alliance: Who needs whom?' (Interview with the deputy foreign minister), Warsaw Voice, 12 November 2002.

Rotfeld, Adam (2003). Speech on the new challenges in Polish security policy, 6 March 2003, available at: http://www.msz.gov.pl/file_libraries/29/253/9.doc.

Schröder, Gerhard (2002). Speech to the German Bundestag, 13 September 2002, available at: http://www.bundeskanzler.de/Reden/7715.440810.htm.

Schröder, Gerhard (2003). 'Unsere Verantwortung für den Frieden', Government Declaration, 13 February 2003, printed in Stichworte zur Sicherheitspolitik, No. 2, February 2003, Presse- und Informationsamt der Bundesregierung, Berlin.

Wheeler, Nicholas and Tim Dunne (2004). 'Moral Britannia? Evaluating the Ethical Dimension in Labour's Foreign Policy', London: Foreign Policy Centre, available at:

http://fpc.org.uk/fsblob/233.pdf.

Wickham-Jones, Mark (2000). 'Labour's Trajectory in foreign affairs: the moral crusade of a pivotal power?', in Richard Little and Mark Wickham-Jones, New Labour's Foreign Policy, Manchester UP.

Zaborowski, Marcin (2003). 'Between Power and Weakness: Poland. A New Actor in the Transatlantic Security', Warsaw: Centre for International Relations, Reports \& Analyses, 8/2003. 